\title{
A migrációs folyamatok hatása a kárpátaljai magyarok számának alakulására
}

\author{
TÁTRAI PATRIK ${ }^{1}$ - MOLNÁR JÓZSEF² - MOLNÁR D. ISTVÁN ${ }^{3}$ - \\ KOVÁLY KATALIN ${ }^{4}$ - ERŐSS ÁGNES ${ }^{5}$ - FERENC VIKTÓRIA ${ }^{6}$ - \\ RÁKÓCZI KRISZTIÁN ${ }^{7}$
}

\section{ABSZTRAKT}

A legutóbbi, 2001-es ukrán népszámlálás szerint Kárpátalján 152 ezer fő vallotta magát magyar nemzetiségúnek, azonban az azóta eltelt időszak népesedési és etnikai viszonyairól nagyon keveset tudni. Különösen a magyar lakosság kivándorlása az, aminek számbavétele nehézséget jelent, és aminek a jelentôsége a 2010-es években - elsősorban a 2014-ben Kelet-Ukrajnában kirobbant fegyveres konfliktus hatására - megnövekedett. Éppen ezért jelen tanulmányban különböző adatforrások: az ukrán és magyar hivatalos statisztikai adatok, valamint két reprezentatív felmérés eredményeit bemutatva keressük a választ arra, hogy hogyan alakult a legutóbbi népszámlálás óta a kárpátaljai magyarok állandó és ideiglenes migrációja, és hogy mindez hogyan befolyásolta a kárpátaljai magyarság létszámát.

Az adatbázisok összehasonlítása rávilágított arra, hogy a különböző módszertannal, különböző aktorok által gyüjtött adatok jelentösen eltérő képet festenek az - egyébként meglehetösen komplex - migrációs folyamatokról. A reprezentatív felmérések szerint, amelyek módszertanuknál fogva vélhetôen jobban tükrözik a mobilitás nagyságrendjét, a kivándorolt magyarok száma 2001 óta 9-14 ezer fö; ez alapján 2017 elején a kárpátaljai magyarok létszáma 130 ezer körül lehetett.

KULCSSZAVAK: Kárpátalja, magyar nemzetiségüek, kivándorlás, demográfia, ideiglenes migráció

${ }^{1}$ MTA CSFK Földrajztudományi Intézet, tudományos főmunkatárs. Tátrai Patrikot a Bolyai János Kutatási Ösztöndíj támogatta.

${ }^{2}$ II. Rákóczi Ferenc Kárpátaljai Magyar Főiskola, Földtudományi és Turizmus Tanszék, tanszékvezető.

${ }^{3}$ II. Rákóczi Ferenc Kárpátaljai Magyar Főiskola, Földtudományi és Turizmus Tanszék, megbízott docens.

${ }^{4}$ MTA CSFK Földrajztudományi Intézet, fiatal kutató.

${ }^{5}$ MTA CSFK Földrajztudományi Intézet, tudományos segédmunkatárs.

${ }^{6}$ Nemzetpolitikai Kutatóintézet, kutató.

${ }^{7}$ Nemzetpolitikai Kutatóintézet, kutató. 
www. metszetek.unideb.hu

\section{TEMATIKUS TANULMÁNYOK - Kárpátalja társadalma}

\section{ABSTRACT}

\section{The impact of recent migration flows on the number of Hungarians in Transcarpathia, Ukraine}

According to the last Ukrainian census in 2001, 152 thousand people declared Hungarian ethnicity in Transcarpathia. Since that time, there is no reliable and up-to-date data on the ethno-demographic development of the region's population. It is especially hard to register the migration flows particularly salient since the outbreak of the armed conflict in East Ukraine in 2014. Based on four data sources (official Ukrainian and Hungarian statistics and two representative surveys), the present study aims at revealing the volume of the permanent and temporary migration of Hungarians in Transcarpathia and its impact on their number. We found that the same migration flow is associated with various figures by each of the data sources conducted with different methods and by different actors. According to the more reliable surveys, 9 to 14 thousand ethnic Hungarians emigrated from Transcarpathia since 2001; consequently, the number of Hungarians is estimated at approximately 130 thousand people in the beginning of 2017.

KEYWORDS: Transcarpathia, ethnic Hungarians, emigration, demography, temporary migration

\section{Bevezetés}

A magyar nemzetiségű lakosság száma - hasonlóan a többi Kárpát-medencei régióhoz - Kárpátalján is csökkenő tendenciát mutat. A legutóbbi, mindmáig egyetlen, 2001-es ukrán népszámlálás szerint Kárpátalján 151,5 ezer fő vallotta magát magyar nemzetiségűnek (158,7 ezer fő pedig magyar anyanyelvűnek), ami az ukrajnai magyarság (156,6 ezer fő) 96,8\%-át tette ki. 2001 óta csak becslések léteznek arról, hogyan alakult a magyarság létszáma. E becslések már a 2001-2010-es, nagyobb exodusoktól mentes időszakra vonatkozóan is jelentősen eltértek egymástól. Molnár és Molnár D. (2005) mintegy 10 ezer fős csökkenést valószínűsített, míg Karácsonyi és Kincses (2010) a magyarországi bevándorlási statisztikákra alapozva 15-20 ezer fős értéket becsült. A különbség elsősorban a migrációs folyamatok számszerűsítéséből adódott.

A 2010 óta eltelt időszakban azonban több olyan fejlemény következett be, ami jelentős hatást gyakorolt a kárpátaljai magyarok vándormozgalmára. Egyrészt 2011-ben lépett életbe Magyarországon az egyszerűsített honosítás intézménye, amely jelentősen megkönnyíti a Magyarországra - illetve az egyéb EU-tagországokba - történő áttelepedést. Másrészt Ukrajnában a 2013 novembere óta tartó geopolitikai események (Euromajdan, kelet-ukrajnai fegyveres konfliktus) hatására a gazdaság tartósan visszaesett, a hadi cselekmények, sorozások pedig a létbiztonságot fenyegetik. Mindezek következtében újabb lendületet kapott a kárpátaljai magyarok kivándorlása. Mindkét tényező serkentette, serkenti a kivándorlást, illetve a külföldi 


\section{TEMATIKUS TANULMÁNYOK - Kárpátalja társadalma}

munkavállalást (azaz a kétlaki életet), azonban a jelenség nagyságáról megbízható becslések nem álltak rendelkezésre.

Éppen ezért jelen tanulmányban különböző adatforrások: statisztikai adatok és reprezentatív felmérések eredményeit bemutatva keressük a választ arra, hogy hogyan alakult a legutóbbi népszámlálás óta a kárpátaljai magyarok állandó és ideiglenes migrációja, és hogy mindez hogyan befolyásolta létszámukat.

Elemzésünkben bemutatjuk a Kárpátaljáról Magyarországra irányuló migrációt mind a kibocsátó, mind a fogadó ország tükörstatisztikái szerint, továbbá ismertetjük két kárpátaljai felmérés (a Molnár D. és Molnár által 2017-ben lebonyolított migrációs felmérés, ${ }^{8}$ valamint a Summa 2017 demográfiai felmérés ${ }^{9}$ ) kivándorlásra vonatkozó adatait. E komplex megközelítéssel remélhetőleg jobban megismerhetővé válnak az elmúlt bő 15 év vándorlási folyamatai, és következtetni tudunk arra is, hogy hány magyar lakos él napjainkban Kárpátalján.

\section{A kárpátaljai magyar népesedés fő tényezői}

Egy adott területen élő népesség számának a változását a természetes szaporodás (születések és halálozások különbözete), valamint a migrációs egyenleg (ki- és bevándorlás mérlege) határozzák meg. Ha viszont a népesség egyik etnikai csoportjának demográfiáját vizsgáljuk, akkor a fenti két, objektívnek nevezhető tényező mellett számításba kell venni a nemzetiségváltás szubjektív tényezőjét is. Utóbbi tartalmazhatja az egyén életében bekövetkező, különböző okokra visszavezethető identifikációs változást, de ennél talán még jelentősebb a generációk között bekövetkező változás (ilyen például, ha egy magyar anya gyermeke nem magyarként nő fel), azaz a demográfiai és az etnikai reprodukció mértéke közötti különbség (ld. Szilágyi N. 2004). Mivel a szubjektív tényezők számszerűsíthetősége meglehetősen nehéz, így a kutatások általában azon változásokat sorolják ide, amiket nem magyaráz a természetes szaporodás és a migráció (ld. pl. Varga E. 2002, Gyurgyík 2004, Szilágyi N. 2004, Kiss 2006).

Ugyanakkor fontos megjegyezni, hogy a három fő tényező közül nemcsak az aszszimiláció, hanem a migráció is rendkívül nehezen követhető statisztikailag. Míg a születések és halálozások rögzítése viszonylag könnyebb feladat, addig a globalizálódó világban egyre élénkebb mobilitás adminisztratív követése, statisztikai számbavétele szinte lehetetlen kihívás. A hivatalos statisztikában meg nem jelenő, be nem jelentett, túlnyomórészt nemzetközi migráció nehezen regisztrálható, éppen ezért e

${ }^{8}$ Állandó és ideiglenes migráció a kárpátaljai magyarok körében az utóbbi években. A kutatás az MTA Domus csoportos szülőföldi ösztöndíja (2016-2017) támogatásával valósult meg.

${ }^{9}$ A projektet a BGA Zrt. támogatta. A kutatást Tátrai Patrik, Molnár József, Kovály Katalin, Erőss Ágnes, Ferenc Viktória, Rákóczi Krisztián és Molnár D. István végezte. 


\section{TEMATIKUS TANULMÁNYOK - Kárpátalja társadalma}

jelenséget Gyurgyík (2006: 80) „rejtett migrációnak” nevezi. Mint azt látni fogjuk, a kárpátaljai emigráció túlnyomó részét éppen ez a rejtett migráció teszi ki. Feladatunkat tovább nehezíti, hogy célunk nem a teljes népesség, hanem csak a magyarok vándormozgalmának követése, márpedig Ukrajnában nem állnak rendelkezésre etnikai bontásban a migrációs adatok.

A kárpátaljai magyarok migrációs folyamatainak követése már a legutóbbi két népszámlálás közötti időszakra vonatkozóan is számos bizonytalanságba ütközött. 1989 és 2001 között a magyarok létszáma 4,2 ezer fővel (2,7\%-kal) csökkent, így számuk 2001-ben 151,5 ezer volt. A megye összlakosságán belüli arányuk 12,5\%ról 12,1\%-ra módosult, de ez a változás az optimista forgatókönyveknek megfelelően zajlott. A migráció szerepét a változásokban igen tág intervallumban becsülték, mintegy 4-30 ezer főnyi Magyarországra áttelepülttel számolva (Molnár és Molnár D. 2005, Kocsis et al. 2006, Karácsonyi és Kincses 2010, Kiss 2012). A népszámlálás eredményeiből kiindulva valószínűleg az alsó értékkel (5 ezer fő körül) kell számolni, de - a magyarországi bevándorlási és állampolgársági statisztikák alapján - ennél jóval többen lehettek azok (akár még egyszer ennyien), akik életvitelszerűen már nem Kárpátalján laktak, de a népszámláláson mégis regisztrálták őket. Ez a jelenség jól mutatja az állandó és az ideiglenes migráció közti határ elmosódottságát, valamint a hagyományos adatfelvételek (pl. népszámlálás) alkalmatlanságát a mobilitási folyamatok követésére.

Az elvándorlás mellett jelentős mértékben, szintén mintegy 5 ezer fővel csökkent a magyar népesség a természetes fogyás miatt (Horváth 2003). A kárpátaljai magyarság természetes szaporulata az 1990-es évek elején váltott át negatív tartományba, és az évtized folyamán az átlagos becsült értéke évi -3\%o volt.

Látható tehát, hogy e két tényező következtében összesen 9-10 ezer fővel fogyatkozott a kárpátaljai magyarság. Ebből az következik, hogy az identifikációs tényezők hatására a magyarság nyeresége 5-6 ezer fő lehetett. Ennek hátterében három összetevő körvonalazódik: egyrészt a cigány népesség önbesorolása, akik közül a státustörvény kedvezményei hatására - Molnár és szerzőtársai becslése szerint több mint 4 ezren vallották magukat magyar nemzetiségűnek (Molnár et al. 2016). Másrészt a szovjet időszakban a különböző kényszerek hatására, retorzióktól tartva magukat ukránnak, vagy szlováknak vallók közül is többen újra magyarként lettek számba véve. Ez a jelenség az ugocsai görög katolikusok között, illetve Ungváron a korábban szlovákként regisztráltak körében volt számottevő (Molnár és Molnár D. 2005, Kocsis et al. 2006). A harmadik tényező pedig a bizonytalan, vagy kettős etnikai identitású népesség önbevallása volt. Ez a csoport a 2001-es népszámlálás időpontjában - a korábbiakhoz képest - nagyobb arányban vallotta magát magyarnak, aminek hátterében szintén a magyarság vállalásának gazdasági előnyei és presztízse állhattak. A 2001-es népszámlálás adataiból az derül ki, hogy a magyar-keleti szláv vegyes házasságból származók 52,8\%-a magyarként, 47,2\%-a pedig ukránként 


\section{TEMATIKUS TANULMÁNYOK - Kárpátalja társadalma}

lett regisztrálva, azaz 2001-ben az etnikai átörökítés Kárpátalján ukrán-magyar viszonylatban közel szimmetrikus volt, minimális magyar asszimilációs nyereséggel (Molnár 2016).

A következőkben a három tényező közül a bizonytalanabbak egyikét, az állandó és ideiglenes migrációnak a magyar népesedésre gyakorolt hatását tekintjük át több adatforrást elemezve.

\section{Vándorlási folyamatok Kárpátalján az ukrán statisztikai adatok tükrében}

Kárpátalja migrációs mérlege Ukrajna függetlenné válását követően veszteségessé vált (Molnár D. 2005). Évente átlagosan 2,5 ezer fővel többen hagyták el a megyét, mint ahányan érkeztek. Az utóbbi évtizedben a kivándorlók száma minden évben meghaladta betelepültekét, ennek megfelelően a 2008 és 2015 közötti időszakban 9078 fővel csökkent Kárpátalja lakossága (Ukrajna Állami Statisztikai Szolgálata 2016), így Ukrajnán belül Kárpátalja rendelkezik a legrosszabb nemzetközi migrációs mérleggel.

A migráció túlnyomó hányadát a belső migráció alkotja, mely nem befolyásolta Kárpátalja összlakosságának számát. A nemzetközi migrációt elsősorban a kivándorlás jelenti; a külföldről Kárpátaljára települők aránya - a FÁK-országokat leszámítva - elenyésző.

A külső migráció átlaga 2015-ben a betelepülők esetében 0,2\%o, a kitelepülők esetében 1,2\%o, a migrációs egyenleg -1\%o volt. Azonban jelentős eltérések voltak az egyes közigazgatási egységek tekintetében. A nemzetközi migráció mérlege minden járás és város esetében negatív előjelű volt, csupán a Nagybereznai járás rendelkezett 0\%o migrációs szaldóval. Szembetűnő, hogy a magyarok lakta síkvidéki közigazgatási egységekből a kivándorlók nagyobb arányban költöztek külföldre. Beregszászból és a Beregszászi járásból 2015-ben a kivándorlók közel 60\%-a külföldre költözött, míg az Ungvári és Nagyszőlősi járásokból közel 45\%, Csapról az elköltözők 1/3-a települt más országba (1. ábra). 
www. metszetek.unideb.hu

\section{TEMATIKUS TANULMÁNYOK - Kárpátalja társadalma}

1. ábra. A kivándorlók megoszlása Kárpátalja közigazgatási egységeiben 2015-ben a kivándorlás helye szerint

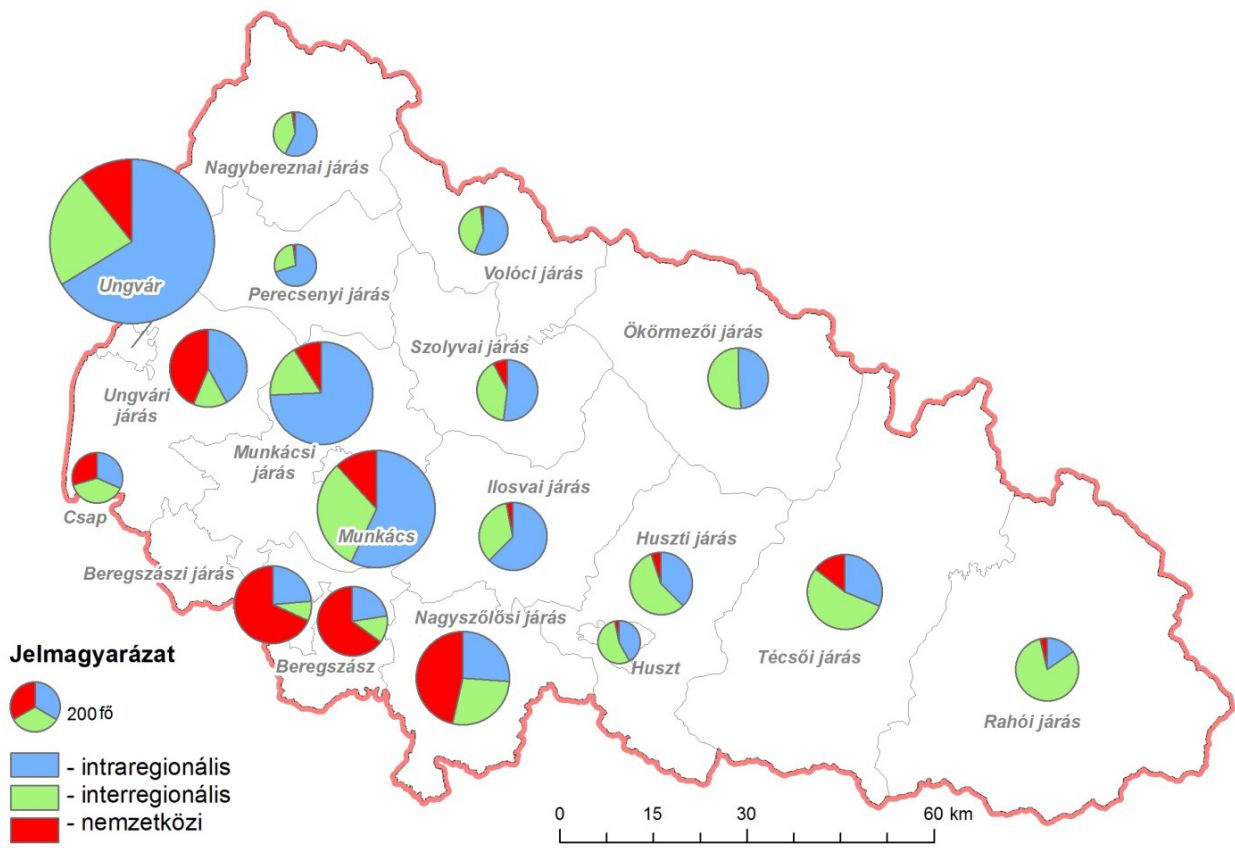

Forrás: Saját szerkesztés a Kárpátaljai Megyei Statisztikai Főhivatal (2016) alapján

Ez egyben azt is jelenti, hogy a kivándorlás jelentősen apasztotta a helyi lakosságot: pl. Beregszászból 232-en költöztek el 2015-ben, ami 9,5\%o-es fogyást jelent. De hasonlóan magas volt a kivándoroltak aránya 1000 főre vetítve Csapon (6,7\%o), a Beregszászi járásban (5,7\%0), továbbá a Nagyszőlősi (2,3\%o) és az Ungvári járásból $(2,6 \% 0)$ is sokan költöztek külföldre, többnyire Magyarországra. A kis arányú betelepülésnek köszönhetően a migrációs veszteség is ezeken a helyeken volt a legjelentősebb: Beregszászon -8,8\%o, Csapon -6,7\%o, a Beregszászi járásban -5,3\%o (2. ábra). 
www. metszetek.unideb.hu

\section{TEMATIKUS TANULMÁNYOK - Kárpátalja társadalma}

2. ábra. A nemzetközi migráció intenzitása Kárpátalja közigazgatási egységeiben 2015-ben (\%o)

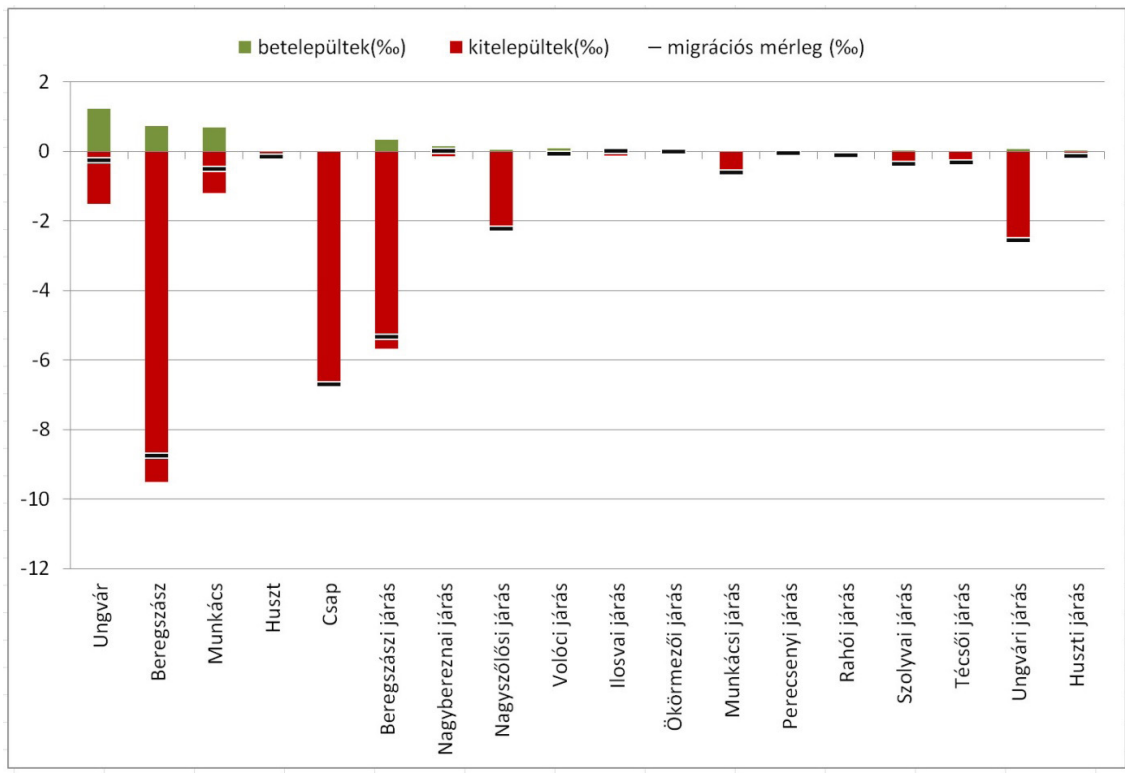

Forrás: Saját szerkesztés a Kárpátaljai Megyei Statisztikai Főhivatal (2016) alapján

Etnikai bontású vándorlási adatok Ukrajnában jelenleg nincsenek nyilvántartva, így a magyarság érintettségét csak közvetett adatokból lehet megállapítani. Mivel a kivándorlás azokban a közigazgatási egységekben a legnagyobb volumenű, ahol a magyarok élnek, ezért feltételezhető, hogy a magyarok az átlagosnál nagyobb mértékben telepednek külföldre - elsősorban Magyarországra. 1995-ben a Magyarországra kivándorlók 85,4\%-a volt magyar nemzetiségű (Zan 2010). Mivel valamilyen szintű kivándorlás más országok felé is irányul, a Magyarországra települtek száma jó közelítéssel tekinthető a kárpátaljai magyarság migrációs veszteségének. 2003-as adatok szerint a nem a FÁK-országokat úti célul választó kivándorlók 22\%-a volt magyar, ami 257 fővel csökkentette az itt élő magyarok számát (Kárpátaljai Megyei Statisztikai Főhivatal 2005). 2005-ben 317 Magyarországra átköltözött kárpátaljai lakost regisztrált a hivatalos statisztika, 2007-ben 281-et, ami a külföldre távozók 30,9 illetve 35,3\%-a volt (Kárpátaljai Megyei Statisztikai Főhivatal 2006, 2008). 2010 és 2011 folyamán viszont összesen mindössze 362 és 360 fő szerepel az emigránsok között, célországok szerinti bontás nélkül (Kárpátaljai Megyei Statisztikai Főhivatal 2011, 2012). Ez alapján az 1990-es évtized évi 400-500 fős fogyásával szemben (Molnár D. 2013) a 2000-es évek első évtizede közepére 200-300-ra, a végére 100-150 főre csökkent a magyarok migrációs vesztesége. Napjainkban az uk- 


\section{TEMATIKUS TANULMÁNYOK - Kárpátalja társadalma}

rajnai válság következtében a kárpátaljai magyarok körében újabb kivándorlási hullám tapasztalható, ami közvetve jelentkezik a statisztikákban is. 2015-ben a külső migráció mérlege Kárpátalján 266-1519=-1253 fó volt. A másfélezer hivatalos kitelepülő 91,2\%-a a négy magyarlakta síkvidéki járásból, valamint a területükön fekvő megyei alárendeltségű városokból származott, ami alapján feltehető, hogy több mint felük magyar volt (Kárpátaljai Megyei Statisztikai Főhivatal 2016).

Az 1990-es évektől kezdve, akárcsak egész Ukrajnában, a migrációnál is jóval nagyobb tömegeket érintett Kárpátalján a szezonális munkaerő-migráció. Ennek hagyományai a szovjet korszakra nyúlnak vissza: a munkaerő-felesleggel rendelkező máramarosi járásokból a nyári félévben tömegek indultak Oroszországba, valamint Kelet-Ukrajnába mezőgazdasági, illetve építőipari szezonmunkára. Ukrajna függetlenné válása után a munkahelyek megszűnése, a kiutazási könnyítések és a jobb kereseti lehetőségek még többeket csábítottak külföldi vendégmunkára.

A kárpátaljai vendégmunkások többsége az 1990-es években valamelyik közeli országban, többnyire Magyarországon, Szlovákiában és Csehországban próbált szerencsét. Az ezredforduló után az oroszországi és az ukrajnai gazdaság fellendülésével párhuzamosan egyre több kárpátaljai (főleg az építőmunkások) talált munkát ezen országok intenzíven épülő nagyvárosaiban. Ma azonban, az ukrajnai rossz gazdasági helyzetnek és az Oroszországgal fennálló feszült kapcsolatoknak köszönhetően, újra a közép- és nyugat-európai országok kerültek a munkavállalók célpontjába.

A statisztika a munkaerő migrációt, annak jelentős részben illegális jellege miatt, nem tudja megfelelően nyilvántartani, így, csak becsléseink lehetnek az érintettek létszámáról. Ezek értelmében, az ezredforduló után a kárpátaljai vendégmunkások száma meghaladta a 100 ezer főt. A kétezres évek csökkenését követően ma újra nő azon kárpátaljaiak száma, akik külföldi munkavállalásra vállalkoznak. Egyes felmérések szerint a megye területéről 125-250 ezer ember dolgozik külföldön (Ihnatolja 2012).

\section{Migráció Ukrajnából Magyarországra a magyar statisztikai adatok tükrében}

Az Ukrajnából Magyarországra irányuló migráció súlya Ukrajnából szemlélve csekély, a magyarországi bevándorlást tekintve viszont jóval jelentősebb. Az Ukrajnából Magyarországra érkezők legalább 70\%-a a magyar kisebbség köréből került ki, és több mint 90\%-uk beszélt magyarul (Kincses 2015, Kész 2008). Ebből részben az is következik, hogy a vándorlás földrajzilag koncentrált, és viszonylag kis távolságot ível csak át: 90\%-uk Kárpátaljáról érkezik, ezen belül pedig 74\% - a magyar kisebbség elhelyezkedésének megfelelően - a határ menti járásokból származik. Magyarországon belül a bevándorlók 80\%-a a központi régióban és Szabolcs-Szatmár-Bereg megyében telepedik le (Karácsonyi és Kincses 2010). A számok alapján tehát az 


\section{TEMATIKUS TANULMÁNYOK - Kárpátalja társadalma}

Ukrajnából Magyarországra irányuló vándorlás jellemzően etnikai migrációnak tekinthető (Feischmidt és Zakariás 2010, Gödri 2010, Karácsonyi és Kincses 2010).

A recens migrációs folyamatokra fókuszálva megállapítható, hogy a hivatalos statisztikák szerint a globális gazdasági válság kitörése óta évről évre csökken a bevándorló (flow) és a Magyarországon tartózkodó (stock) ukrán állampolgárok száma, továbbá a kiadott tartózkodási és munkavállalási engedélyek száma is (3. ábra). Ezzel szemben az ukrán krízis kezdete óta (tehát lényegében 2014-től) a hírek a kárpátaljaiak tömeges Magyarországra vándorlásáról, illetve munkavállalásáról számoltak be egyrészt a katonai behívók elől, másrészt a kilátástalan gazdasági körülmények miatt (Kovály et al. 2017).

3. ábra. Az Ukrajnából Magyarországra irányuló migráció a születési hely és az állampolgársági statisztikák tükrében, 2009-2016

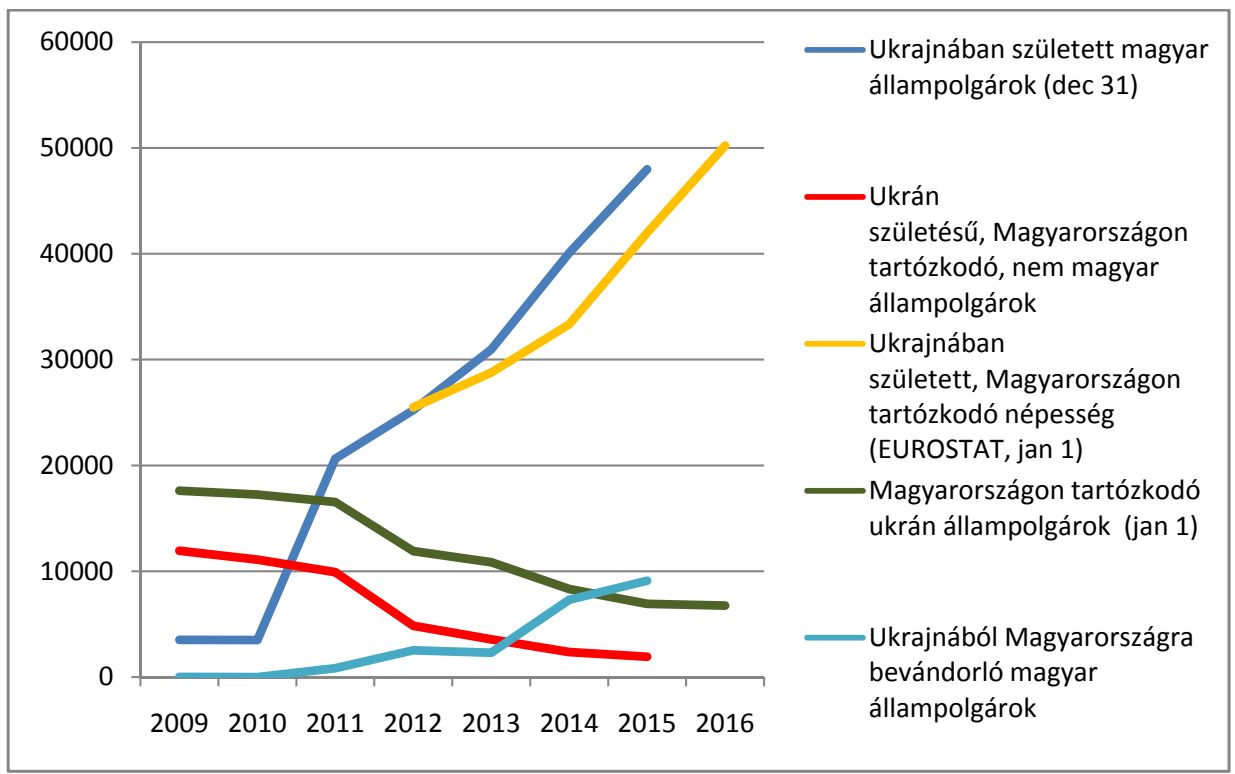

Forrás: Saját szerkesztés

A fenti ellentmondás háttere, a számokból kirajzolódó folyamatok értelmezése összetett kérdés. Az ukrán állampolgárok számának visszaesése 2008 és 2011 között elsősorban a gazdasági válságnak tulajdonítható, hiszen ekkor a szűkülő munkalehetőségek miatt a többnyire a munkaerőpiac alsó szegmensében dolgozó ukrán állampolgárok visszakényszerültek Ukrajnába (Çağlar 2013). Ezzel szemben a globális gazdasági válság utáni időszakban a csökkenés már főként nem a magyaror- 


\section{TEMATIKUS TANULMÁNYOK - Kárpátalja társadalma}

szági gazdasági okokra, hanem az egyszerűsített honosítási eljárás életbe lépésére vezethető vissza. A magyar állampolgárság tömeges megszerzése miatt 2011 után a szomszédos országok viszonylatában az állampolgárságon alapuló migrációs statisztikák már nem alkalmasak a valós folyamatok nyomon követésére. Különösen nagy arányban igényeltek magyar állampolgárságot a kárpátaljai magyarok, akik - esetleges Magyarországra költözésükkor, magyar állampolgárként - így már nem kerültek be a vonatkozó bevándorlási statisztikákba (Tátrai et al. 2017).

Ezt támasztják alá a születési hely szerinti adatok is: az elmúlt években megduplázódott a Magyarországon élő Ukrajnában született magyar állampolgárok száma (2011: 20 ezer fö, 2015: 48 ezer fó). ${ }^{10}$ Mivel 2011 és 2015 között mindössze 6100 magyarországi lakcímmel rendelkező ukrán állampolgár kapott magyar állampolgárságot, ami messze elmarad a fenti, 28 ezer főnyi különbségtől, így a növekmény egyértelmúen az Ukrajnából Magyarországra vándorló magyar állampolgároknak tudható be, akik az állampolgársági törvény módosítása után még ukrajnai lakosként szereztek magyar állampolgárságot. ${ }^{11}$

Jól látható tehát, hogy az ukrán statisztikákkal szemben a magyar adatok jelentős volumenű áttelepedésről számolnak be. A folyamat intenzitása különösen felerősödött a 2014-es kelet-ukrán konfliktus kitörését követően. Míg Karácsonyi és Kincses (2010) adatai alapján 2001 és 2008 között a kárpátaljai magyarság 5-6\%-a (kb. 8 ezer fö) települt át Magyarországra, ${ }^{12}$ addig 2008 után az összes áttelepült lakos száma - a születési ország szerinti statisztikák alapján - elvileg elérhette a 35 ezer főt. ${ }^{13}$ Azonban figyelembe véve e statisztikák pontatlanságát (esetleges többszörös regisztráció a cirkuláris migráció és a nehezen követhető ingázások miatt; csak papíron létező átköltözések), illetve leszámítva a nem magyar nemzetiségú áttelepülők mintegy 20\%-os arányát, ennél az értéknél valószínúleg jóval kevesebb kárpátaljai magyar (kevesebb mint 20 ezer fő) költözhetett át ténylegesen Magyarországra 2008 óta. ${ }^{14}$ Összességében tehát - az egyébként meglehetősen ellentmondásos magyarországi statisztikai adatok alapján - a 2001-es ukrán népszámlálás óta a kárpát-

${ }^{10}$ Az EUROSTAT adatai a fenti időpontokra némileg eltérő értékeket, de hasonló folyamatokat mutatnak (25 485-ról 50222 före).

${ }^{11}$ A TANDEM 2016 felmérés eredményei is megerősítették, hogy a magyar állampolgárság megszerzése jelentősen megkönnyítette a migrációt és bevett boldogulási stratégiává vált a magyarok (és nem magyarok) számára egyaránt (Szanyi et al. 2017). Az egyszerűsített honosítási eljárásnak köszönhetően 2011 és 2014 áprilisa között mintegy 70 ezren kaptak magyar állampolgárságot Ukrajnában (Soltész és Zimmerer 2014); az összes igénylés száma 2016 júniusáig pedig eléri a 149 ezret (Kántor 2016), ami lényegében megegyezik a kárpátaljai magyarok 2001-ben rögzített számával.

${ }^{12}$ Karácsonyi és Kincses (2010) BÁH-adataira alapozott eredményeinek némileg ellentmondanak a 2011-es népszámlálási adatok, amelyek szerint 2001 és 2011 között évente 300-400 fő között mozgott az ukrajnai születésű betelepülők száma (KSH 2016).

${ }^{13}$ 2009. december 31.: 3,5 ezer magyar és 12 ezer nem magyar állampolgár; 2015. december 31.: 48 ezer magyar és 2 ezer nem magyar állampolgár.

${ }^{14}$ Ezt alátámasztja az is, hogy a 2016-os mikrocenzus szerint 2016. október 1-jén Magyarországon csak 37 ezer Ukrajnában született lakos élt (KSH 2017). 


\section{TEMATIKUS TANULMÁNYOK - Kárpátalja társadalma}

aljai magyarok migrációs vesztesége (csak Magyarország vonatkozásában) 21-36 ezer fő körülire becsülhető.

A kárpátaljai magyarok ideiglenes magyarországi tartózkodására vonatkozóan friss adatok nem állnak rendelkezésre. A 2000-es évek végén a szakértők mintegy 20 ezer ukrán állampolgárságú munkavállalóval számoltak (Juhász et al. 2010), amihez hozzá kell még számolni a Magyarországon tanulókat (több mint 2 ezer fő), illetve az egyéb Magyarországon tartózkodó lakosokat (pl. nyugdíjasok). Az egyszerūsített honosítás bevezetésével ezen csoportok nyomon követése gyakorlatilag lehetetlen, így magyarországi adatforrások alapján becsülni sem lehet az ideiglenes migráció mértékét.

\section{Migrációs felmérés 2017}

\section{CÉLKITÚZÉSEK, MÓDSZEREK}

A kárpátaljai magyar migrációs adatoknak az előzőekben bemutatott bizonytalanságai tették szükségessé azt a felmérést, amelynek célkitűzése a kárpátaljai magyarság vándormozgalmának számszerűsítése, valamint a vándorlásuk jellegének, időtartamának és céljának feltárása volt. A kutatás során 126 mintavételi ponton reprezentatív, a kárpátaljai magyarság több mint 5 százalékára kiterjedő felmérést végeztünk Kárpátalja magyarlakta településein 2017. január és március között. A 2001-es adatok alapján így átlagosan 1203 kárpátaljai magyarra jutott egy mintavételi pont. A felmérés során a mintavételi pontot alkotó (azaz a helyi kérdezőbiztos közvetlen szomszédságában élő és általa jól ismert) 20 család migrációs magatartására vonatkozó információkat vettünk fel. Az adatgyűjtés kiterjedt a családok összetételére, az ideiglenesen vagy állandó jelleggel az adott településen kívül élők tartózkodási helyére, tartózkodásának céljára (munkavállalás, tanulmányok, egyéb), hazalátogatásainak gyakoriságára, időtartamára.

A kérdőíven a mintába került családok tagjainak korát, nemét, nemzetiségét, foglalkozását, valamint az ideiglenes (munkavállalási, illetve tanulmányi célú) migrációban való esetleges részvételük jellegét rögzítettük. A kérdőív külön lapjára kerültek a 2010-2016-os időszak során elköltözöttek adatai. A begyűjtött adatok forrása elsődlegesen az adott háztartásban élők személyes közlése (általában egy háztartásból egy adatközlővel), azonban ha a mintába eső háztartás tagjait nem lehetett elérni, akkor más - a személy megfelelő adataival tisztában levő - személy, általában a szomszéd, távolabbi rokon közlésére támaszkodtunk. Vizsgálatainkhoz - tekintettel a kárpátaljai magyarok különböző települési viszonyaira - kétféle mintavételi módszert alkalmaztunk: 


\section{TEMATIKUS TANULMÁNYOK - Kárpátalja társadalma}

- A magyar többségű településeken területi alapút, amelybe egymás mellet élő 20 család (háztartás) került. A mintaterület kiválasztásában a lekérdező lakhelye játszotta a döntő szerepet, mivel úgy véltük, illetve ezt más kutatások tapasztalatai is megerősítették (Gyurgyík 2004), hogy az adatközlők szívesebben állnak szóba egy helyi kérdezővel, mintsem idegennel.

- A szórványtelepüléseken magyar többségű mintát az előző módszerrel nem kaptunk volna, így itt magyar jellegű hálózatokra kellett építenünk. A kínálkozó lehetőségek közül a magyar iskolák tanulói, végzősei, illetve azok családjai bevonását választottuk.

Az első típusú mintavétel során az egy tömbben élő 20 háztartás (amit a családdal azonos értelemben használunk) tagjainak az adatait rögzítettük. A második típusú mintavételnél, amit a szórványmagyarság településein alkalmaztunk, a magyar iskola egy (vagy, ha kicsi az osztály létszáma, két) osztálya 20 tanulója családtagjainak az adatait rögzítettük.

A minta járások, megyei jelentőségủ városok, illetve települések szerinti eloszlásának megtervezésekor próbáltuk azt megfeleltetni a kárpátaljai magyar népesség 2001-es népszámlálás által rögzített eloszlásának, az előforduló torzításokat súlyozással korrigáltuk.

A felmérés során összesen 8781 személy adatait sikerült összegyűjteni. A mintavétel jellegéből, valamint az etnikailag vegyes családok magas arányából adódóan, a mintába jelentős számban kerültek nem magyarok is. A magyar nemzetiségúek száma 7753 volt, a teljes minta 88,3\%-a, ukránok alkották a 10,9\%-ot (954fó), egyéb nemzetiségek (fóleg oroszok és romák) és ismeretlen etnikumúak pedig 0,8\%-nyian kerültek be.

\section{EREDMÉNYEK}

A vizsgálat keretein belül a kérdezők felmérték a 2010-2016 között elköltözöttek alapadatait. Ez a hétéves periódus nem ad lehetőséget a migráció időbeli tendenciáinak az alapos elemzésére, ám egy fontos mozzanat a felszínre került: 2015-ben ugrásszerűen emelkedett az elköltöző kárpátaljai magyarok száma. 2010-14-ben a vizsgált csoporton belül átlagosan évi 24 elköltözés történt, 2015-16-ban ezzel szemben 69. 2010-14-ben az emigránsok 75,4\%-a, átlagosan 18 fó évente, Magyarországot választotta lakóhelyéül, ez az arány 2015-16-ra alig módosult (73,7\%, 51 fö/év).

Hogy megítélhessük, milyen mértékủ volt a kitelepülés a teljes kárpátaljai magyar nemzetrész vonatkozásában, ismernünk kellett a minta nagyságát, amelyre a 


\section{TEMATIKUS TANULMÁNYOK - Kárpátalja társadalma}

fenti számok vonatkoztathatóak. Automatikusan nem számolhattunk az elemzésbe bekerült 7753 fős magyar mintával, mert:

- A kiköltözöttek nemzeti hovatartozását nem ismerjük, köztük, ha nem is nagy számban, de lehettek nem magyar nemzetiségűek is, körülbelül olyan arányban, ahogy a teljes mintába is bekerültek. Ezért, a teljes népességre való átszámításkor nem csak a mintába került magyar nemzetiségűek számát kellett alapul vennünk, hanem a számításba vont kérdőíveken szereplők teljes számát, etnikai hovatartozástól függetlenül.

- A beérkezett kérdőívek feldolgozása során arra a következtetésre jutottunk, hogy nem minden kérdezőnek sikerült az elköltözöttekre vonatkozó részt megfelelő alapossággal kitölteni. Az ilyen kérdőíveket, az eredmények torzításának elkerülése érdekében, jobbnak láttuk kihagyni az elemzés ezen részéből.

Így összességében a kárpátaljai magyarok emigrációs létszámvesztésének a számításához csupán 111 mintavételi pont anyagait, azaz 7456 személy adatait használtuk fel. Hogy a 7456 személyre vonatkozó adatainkat arányosan kiterjeszthessük a teljes, az általunk a 2010-es évek elején 135-140 ezer fősre becsült kárpátaljai magyar nemzetrészre, 18,5-es szorzót használtunk.

A vázolt megfontolások figyelembe vételével azt az eredményt kaptuk, hogy a kárpátaljai magyarság migrációs eredetű (a külföldre való kitelepülésből adódó) fogyása a 2010-14-es időszakban évente átlagosan 430-440 fő́t tett ki (4. ábra). A kitelepülők 75,4\%-a, közel 330 fő, Magyarországot választotta új lakhelyéül. A kelet-ukrajnai konfliktussal összefüggő politikai-gazdasági válság nyomán a külföldre átköltöző kárpátaljai magyarok száma megugrott, elérve az évi 1250-1300 főt. Ezek zöme (73,7\%-a, évi átlagban 900-950 fő), akárcsak korábban is, az anyaországban talált új hazára. ${ }^{15}$

${ }^{15}$ A már megvalósult kitelepedésekhez hasonlóan a tervezett kitelepedéseknél is a döntő többség Magyarországot választaná. A 15-29 évesekre fókuszáló GeneZYs 2015 kutatás szerint a kitelepedést tervezők 76\%-a Magyarországra költözne (Papp et al. 2017). Ugyanez az arány a TANDEM 2016 kutatás szerint 83\% (Szanyi et al. 2017). 
www. metszetek.unideb.hu

\section{TEMATIKUS TANULMÁNYOK - Kárpátalja társadalma}

4. ábra. Az elköltözöttek évi száma a kárpátaljai magyar népességen belül a 2010-2016-os időszakban a migrációs felmérés alapján

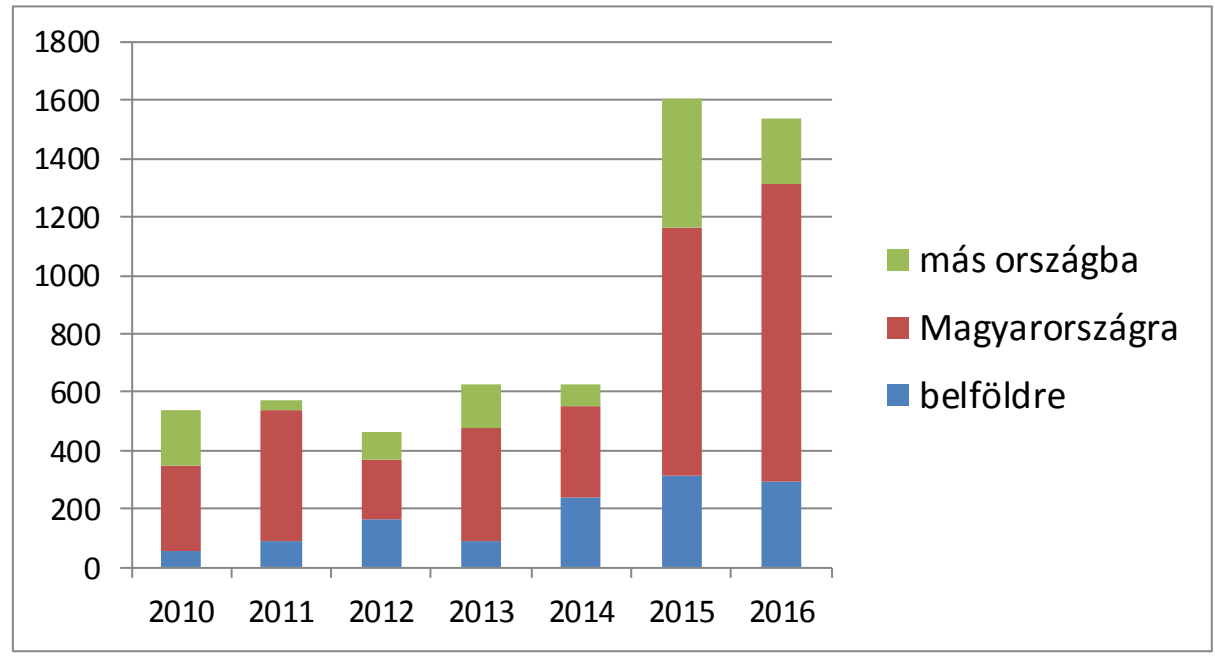

Forrás: Saját szerkesztés

Ahogy már korábban jeleztük, az állandó migráció mellett a kárpátaljaiak életében kiemelkedő szerepe van az ideiglenes - munkavállalói és tanulói - migrációnak. A felmérésünk által érintett ismert munkahelyű emberek 34,9\%-a, 980 fő dolgozott 2017 elején külföldön. Ez a felmérés által érintett kárpátaljai magyarok 12,7\%-át jelenti. Azaz - a kárpátaljai magyarok számától függően - 2016 folyamán 16-17 ezer kárpátaljai magyar dolgozhatott külföldön.

2016-ban a kárpátaljai magyar vendégmunkások a legnagyobb arányban, közel fele részben, Magyarországon dolgoztak (5. ábra). Ennek okát egyértelműen a nyelvi-kulturális azonosságban, illetve a hagyományosan kiépült kapcsolatrendszerben látjuk. Magasan kiemelkedik a mezőnyből a második Csehország is, ahol a felmért külföldön munkavállalók 31,9\%-a dolgozott. A csehországi foglalkoztatók népszerüségét a magyarországinál magasabb kereseti lehetőségek magyarázzák, de némileg hozzájárulnak ehhez a történelmi kapcsolatok és a földrajzi közelség is. A nyugat-európai jóléti társadalmak közül a vizsgált külföldi munkavállalók legnagyobb arányban Németországot választották, bár, arányuk a 10\%-ot sem érte el (5. ábra). ${ }^{16}$

\footnotetext{
${ }^{16}$ Hasonló eredményre jutott a TANDEM 2016 is. Előbbi szerint a legalább 1 hónapot külföldön dolgozók közül - ami a magyar minta 19\%-át jelentette - Magyarországot 53\%, míg Csehországot 37\% választotta (Szanyi et al. 2017). A GeneZYs 2015 szerint Magyarországra a munkavállalók 63\%-a, Csehországba pedig 17\%-a ment (Papp et al. 2017).
} 


\section{TEMATIKUS TANULMÁNYOK - Kárpátalja társadalma}

5. ábra. A mintába került külföldön dolgozó kárpátaljai magyarok megoszlása a munkavállalás országa szerint

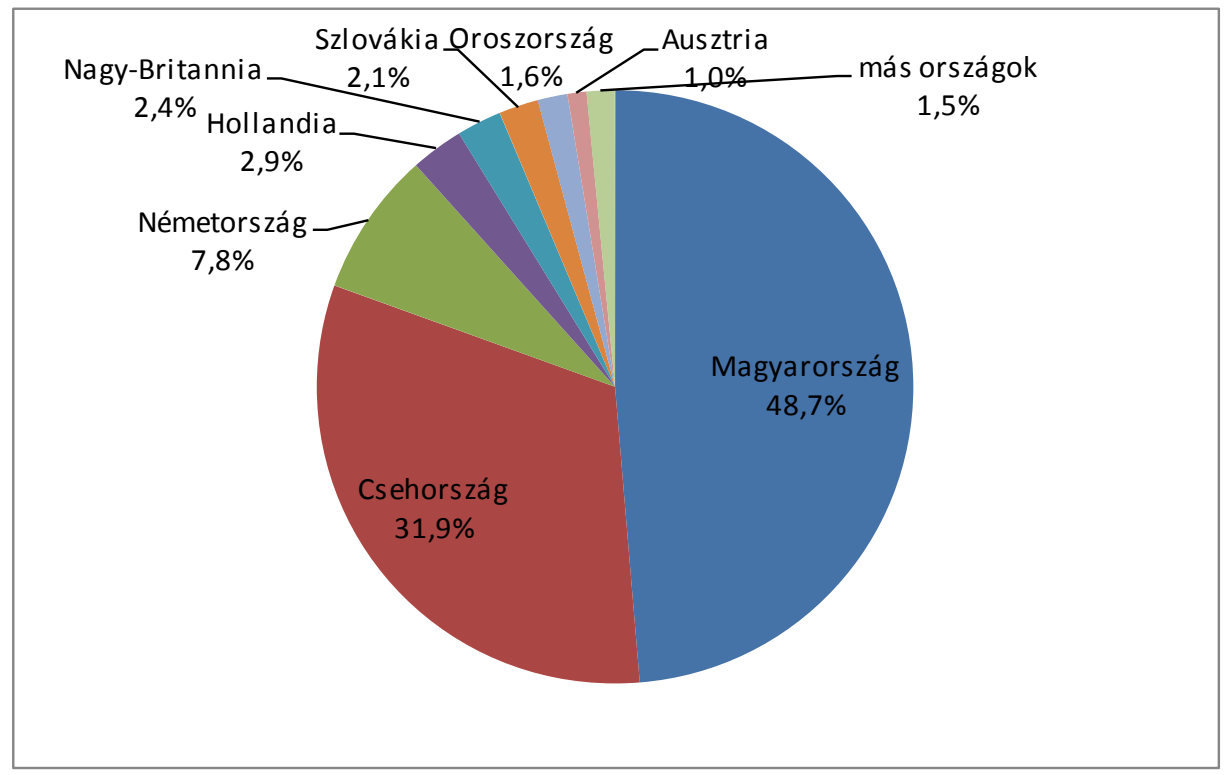

Forrás: Saját szerkesztés

Magyarországon belül a munkavállalás helyszíneinek rangsorát magasan kiemelkedve a főváros vezeti: a jelen kutatás adatai alapján ott dolgozik az anyaországban munkát vállaló kárpátaljai magyarok több mint 45\%-a. Budapest gazdasági súlyát figyelembe véve ez érthető is, mint ahogy a prosperáló gazdaság magyarázza a földrajzilag Kárpátaljától távol eső Győr második helyét is a listán, ahol a Magyarországon dolgozók közel 10\%-a helyezkedett el. Az elmúlt években jelentősen visszaesett a Kárpátaljához közel fekvő térségek részesedése: a két közeli nagyváros, Debrecen és Nyíregyháza egyaránt 3,2\%-kal szerepel a listán.

Előzetes feltételezéseink szerint népes csoportot alkotnak a külföldön tanuló kárpátaljai magyar fiatalok is. A mintában főiskolai, illetve egyetemi hallgatóként azonosított 201 személy közül 197-re vonatkozóan kaptunk a tanulmányok helyéről adatot. 70-en tanultak 2016-ban külföldön (nevezetesen Magyarországon), ami a felsőfokú képzésben részt vevők 35,5\%-át jelenti. A nevesített magyarországi egyetemi központok között Debrecen és Budapest vezetett (megfelelően 47,4 és 33,3\%), valamint Nyíregyháza is népszerűnek bizonyult (14,0\%-kal). 


\section{TEMATIKUS TANULMÁNYOK - Kárpátalja társadalma}

Az iskolák, szakközépiskolák felmért 1180 diákja között jóval kisebbnek bizonyult a külföldön tanulók aránya: 70 tanulóról kaptunk ilyen adatot, ami 8,5\%-át jelentette azoknak, akik tanulmányi helyéről rendelkeztünk információval (821fő). Ezek zöme (66 fö, 8\%) ugyancsak Magyarországon tanult. Az anyaországban tanuló általános és középiskolások tanintézményei földrajzilag jobban szóródtak, bár, Debrecen, Budapest és Nyíregyháza itt is kiemelt helyen állt (megfelelően 25,9\%, 14,8\% és $11,1 \%)$.

Összességében 2017 elején a külföldön (szinte kizárólag Magyarországon) tanulók az összes ideiglenesen külföldön tartózkodó kárpátaljai magyarok 12,4\%-át alkották, számuk közel 2500 fő volt.

A migrációs felmérés alapján tehát 2010 és 2016 között összesen közel 5000 magyar vándorolt ki Kárpátaljáról, közülük mintegy 3500-an Magyarországra. A felmérés sajnos nem terjedt ki a 2001-2010 közötti időszakra, mindenesetre, ha a 201014-es időszak adatait alkalmazzuk a korábbi évekre is - ami alapvetően egybecseng Molnár és Molnár D. (2005) migrációs előrebecslésével -, akkor további 4 ezer fővel számolhatunk. Így összességében a 2001-2016 közötti időszakban a magyarok száma 9 ezer fóvel csökkenhetett az elvándorlás miatt. Emellett pedig napjainkban közel 20 ezer magyar tartózkodik hosszabb-rövidebb ideig külföldön munkavállalási vagy tanulási céllal.

\section{Summa 2017 (a kárpátaljai magyarok demográfiai felmérése)}

\section{CÉLKITŰZÉSEK, MÓDSZEREK}

Mivel Ukrajnában 2001 óta nem tartottak népszámlálást, így a magyarok számáról, demográfiai jellemzőiről a népszámlálás óta eltelt időszakra nem voltak pontos és megbízható információk. Éppen ezért a kutatás fő célja a magyar közösség számának, települési megoszlásának, egyes demográfiai jellemzőinek (nem és kor szerinti megoszlás), felekezeti megoszlásának, végzettségének, valamint külföldi munka- és tanulási célú migrációjának a felmérése volt.

A felmérés módszertana hasonlított az előzőekben bemutatott migrációs felmérésére. A demográfiai adatfelvétel Kárpátalja 111 magyarlakta településére terjedt ki, ahol a 2001-es népszámlálás szerint legalább 100 magyar nemzetiségú lakos élt. A terepi kutatás 312 mintavételi ponton, véletlen mintavételezéssel zajlott, és kiterjedt a kárpátaljai magyarság 2001-es létszámának 15\%-ára. Az egy településre eső mintavételi pontok számát a 2001-es népszámlálás alapján a magyar lakosság eloszlásának függvényében határoztuk meg. Ily módon, átlagosan 500 kárpátaljai magyarra (2001-es adatok szerint) jutott egy mintavételi pont. Egy mintavételi pont 20 részben vagy teljesen magyar háztartásból állt, amelynek összes tagjáról (beleértve a 2001 óta elvándoroltakat és elhunytakat) begyújtöttük a vonatkozó 


\section{TEMATIKUS TANULMÁNYOK - Kárpátalja társadalma}

alapinformációkat. A kérdezőbiztosok az adott mintavételi pont összes háztartásában rákérdeztek a háztartás minden lakosának nemére, korára, nemzetiségére, anyanyelvére, felekezetére, legmagasabb iskolai végzettségére, fó foglalkozására, az 1 hónapot meghaladó külföldi tartózkodás hosszára és helyére, valamint a legutóbbi népszámlálás időpontjában az életvitelszerű tartózkodási helyére.

A kutatás egyik kardinális kérdése a mintavételezés volt. Vizsgálatainkhoz - tekintettel a kárpátaljai magyarok különböző települési viszonyaira - háromféle mintavételi módszert alkalmaztunk:

- A magyar többségú településeken területi alapút, amelybe egymás mellet élő (területileg összefüggő) 20 magyar család (háztartás) került. ${ }^{17}$ A kezdő háztartást és a haladás irányát a helyi viszonyokat jól ismerő kérdezőbiztos és a kutatás vezetői közösen jelölték ki úgy, hogy a mintavételi pontok ne fedjék egymást, illetve elérhető legyen 20 magyar család egy összefüggő területen. A mintavételi módszer reprezentativitását az biztosítja, hogy Kárpátalja magyar többségű falvaiban nem számottevő a lakóhelyi szegregáció, azaz nincs érdemi elkülönülés a különböző szociális mutatók alapján. Ez alól kivételt csak a cigány népesség jelent, akik nagy számban élnek elkülönülve, telepi körülmények között. Az ő felmérésükre jelen kutatás nem vállalkozott.

- A nagyobb városokban, ahol a magyarság nem egy tömbben, hanem általában szétszórva él, népességregiszterekből történt a mintavételezés. Ennek során egy, az ezredfordulón összeállított népességregiszterből leválogattuk az adott település jellemző magyar családneveit, és az így kapott listáról lettek véletlenszerűen kiválasztva a kérdezőbiztosok által lekérdezendő háztartások.

- A szórványtelepüléseken, ahol az etnikai vegyesség miatt nem feltétlenül vannak magyar családnevek, illetve a szórt jelleg miatt az első módszer sem alkalmazható, egy harmadik módszert, az általunk „területi hólabdának” nevezettet vezettünk be. E módszer szerint nem egy előre kijelölt szomszédság, hanem mindig a legközelebbi magyar háztartás került lekérdezésre (összesen itt is 20 magyar háztartás alkotott egy mintavételi pontot).

A lekérdezés 2017 nyarán valósult meg. A felmérés során összesen 23033 személy adatait sikerült rögzíteni. A mintavétel jellegéből, valamint az etnikailag vegyes családok magas arányából adódóan, a mintába jelentős számban kerültek nem magyarok is. A magyar nemzetiségúek száma 20688 volt, a teljes minta 89,8\%-a, az ukránok 3,3\%-ot (769 fó), a magyar-ukrán kettős identitást vállalók 5,6\%-ot tettek ki (1292 fő), míg egyéb nemzetiségek képviselői (főleg oroszok és romák) és ismeretlen etnikumúak 1,3\%-nyian (284 fó) kerültek be.

\footnotetext{
${ }^{17}$ Ehhez hozzáadódnak az esetleges üres és nem magyar háztartások, mivel a kérdezőbiztosoknak az egybefüggő területen elhelyezkedő összes háztartás adatait rögzíteniük kellett egészen addig, amíg meg nem lett a 20 magyar háztartás.
} 


\section{TEMATIKUS TANULMÁNYOK - Kárpátalja társadalma}

A magyar népesség számát a mintába került népesség természetes szaporodása és migrációs egyenlege alapján számítottuk ki a 2001-es népszámlálás adatainak továbbvezetésével. Szubjektív tényezőket, így az egyéni identifikáció változásait a kutatás nem vizsgálta. A kapott adatok alapján településenként meghatároztuk a születési, a halálozási és a migrációs rátákat a 2002-2017-es időszakra. Kivonva a halálozási ráták értékeit a születésikéből és hozzáadva a migrációs rátákat kaptuk a magyarok települési lélekszámváltozásának rátáit a 2002-2017-es időszakra. Ezzel szoroztuk a magyaroknak a 2001-es népszámlálás alkalmával összeírt települési számát a megfelelő jelenlegi értékek meghatározásához. A 2002 és 2017 között külföldre távozottak számát a települési migrációs ráták összesítésével határoztuk meg: mivel a kárpátaljai magyarok számát a belső vándorlás kevéssé befolyásolja, ezért a kapott migrációs egyenleg lényegében a nemzetközi vándorlás szaldóját adja.

\section{EREDMÉNYEK}

A településenként meghatározott migrációs ráták összesítésével azt az eredményt kaptuk, hogy bő 15 év alatt 14,5 ezer magyar költözött külföldre, továbbá hatszáz Ukrajna belső részeire, miközben a bevándorlás a nevezett irányokból csupán háromszáz, illetve száz fő körül alakult. Az emigráció időbeli dinamikája hasonló, mint amit a migrációs felmérés mutatott: 2014-től kezdődően jelentősen megemelkedett a kivándorlók száma. Míg a 2002-2013 közötti időszakban évi átlagos 900-950 fő költözött külföldre, addig a 2014-es geopolitikai változásokat követően ez a szám átlagosan 1200-1300 főre ugrott (6. ábra).

6. ábra. Az elköltözöttek évi száma a kárpátaljai magyar népességen belül a 2002-2016-os időszakban a Summa 2017 alapján. A Magyarországra költözöttek sötétzölddel jelölve

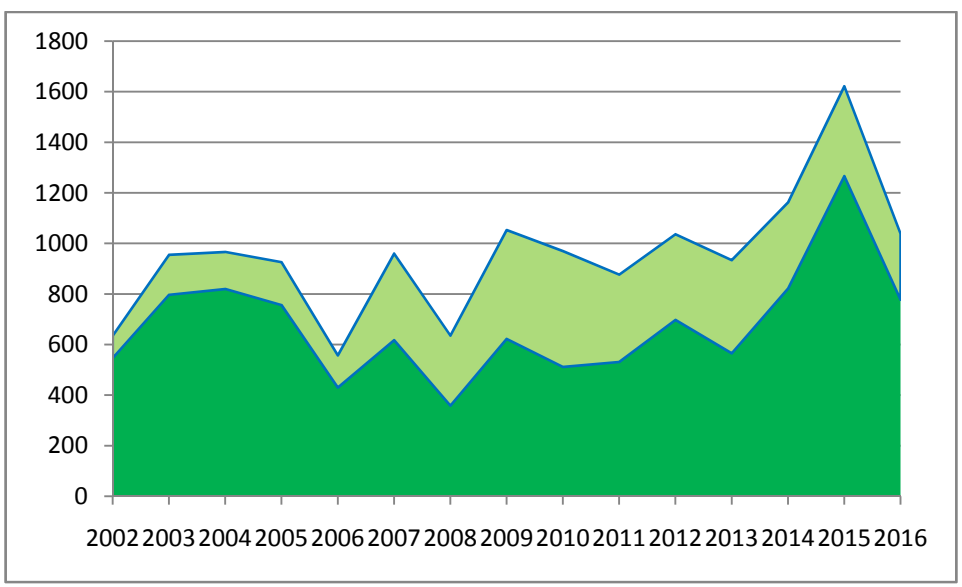

Forrás: Saját szerkesztés 


\section{TEMATIKUS TANULMÁNYOK - Kárpátalja társadalma}

Bár a kivándorlók többsége (összességében 70,4\%) a vizsgált időszakban végig Magyarországra települt, a 2000-es évek második felében, amikor az Ukrajna és Magyarország közötti gazdasági különbségek csökkentek, Magyarország népszerűsége is csökkent. Ebben az időszakban csak a kivándorlók 50-60\%-a választotta Magyarországot, míg egyre többen költöztek Németországba, Csehországba, Nagy-Britanniába és Szlovákiába. Bár nem számít kivándorlásnak, de az Ukrajna belső részei felé irányuló migráció is ekkor volt a legjelentősebb. Utóbbi - a végig szerény mértékű oroszországi kitelepüléssel együtt - 2014-től kezdve azonban lényegében megszűnt. Az utóbbi években, köszönhetően az ukrajnai (geo)politikai és gazdasági válságnak, illetve a magyar nemzetpolitika lépéseinek (ld. Tátrai et al. 2017) a kivándorló kárpátaljai magyarok domináns célországa újra Magyarország, amit az emigrálók 3/4-e választ.

Az állandó migráció mellett a Summa 2017 kutatás vizsgálta az ideiglenes migrációt is, ami fontos adalék a magyar népesség létszámának meghatározásához. A kutatás folyamán mindenkit, akiről kárpátaljai lakhelyén azt mondták, hogy még ott lakik, kárpátaljai lakosnak tekintettünk - függetlenül attól, hogy akár évi 11 hónapot töltött más országban.

Az ideiglenes külföldi tartózkodást a 2016 folyamán külföldön eltöltött hónapok számán és célországán keresztül kíséreltük meg megragadni. A teljes magyar népesség 22\%-a (az aktív népesség 30\%-a) számolt be arról, hogy legalább 1 hónapot töltött külföldön 2016-ban, azaz a különböző célú ideiglenes, határon átívelő mozgások mintegy 27-28 ezer magyart tartanak mozgásban. A külföldre járók 2/3-a (ami 18-19 ezer főt jelent) hosszabb időtávot (legalább 3 hónapot) töltött külföldön; jellemzően ők azok, akik dolgoznak, illetve tanulnak a külföldi célországokban.

A kárpátaljai magyarok körében a külföldi munkavégzés - és egyéb célú tartózkodás - legnépszerúbb célországa továbbra is Magyarország. A külföldön legalább egy hónapot tartózkodók közel 2/3-a Magyarországot preferálja, amit Csehország és Németország követ. A többi ország részesedése jóval alacsonyabb, közülük csak Nagy-Britannia, Hollandia és Szlovákia részesedése éri el az 1\%-ot. Azonban ha a hosszabb távú (3 hónapot elérő) külföldi tartózkodást vizsgáljuk, akkor jól látszik, hogy Magyarország népszerűsége csökken (50\%), míg a távolabbi desztinációk (elsősorban Csehország) szerepe nő. Rajtuk kívül csak Németország, Nagy-Britannia, Hollandia, Szlovákia és Oroszország részesedése éri el az 1\%-ot (7. ábra). 
www. metszetek.unideb.hu

\section{TEMATIKUS TANULMÁNYOK - Kárpátalja társadalma}

7. ábra. A 2016 folyamán hosszabb időt külföldön tartózkodó kárpátaljai magyarok megoszlása célországonként a Summa 2017 szerint (külső kör: legalább 3 hónapot külföldön töltők; belső kör: legalább 1 hónapot külföldön töltők) (\%)

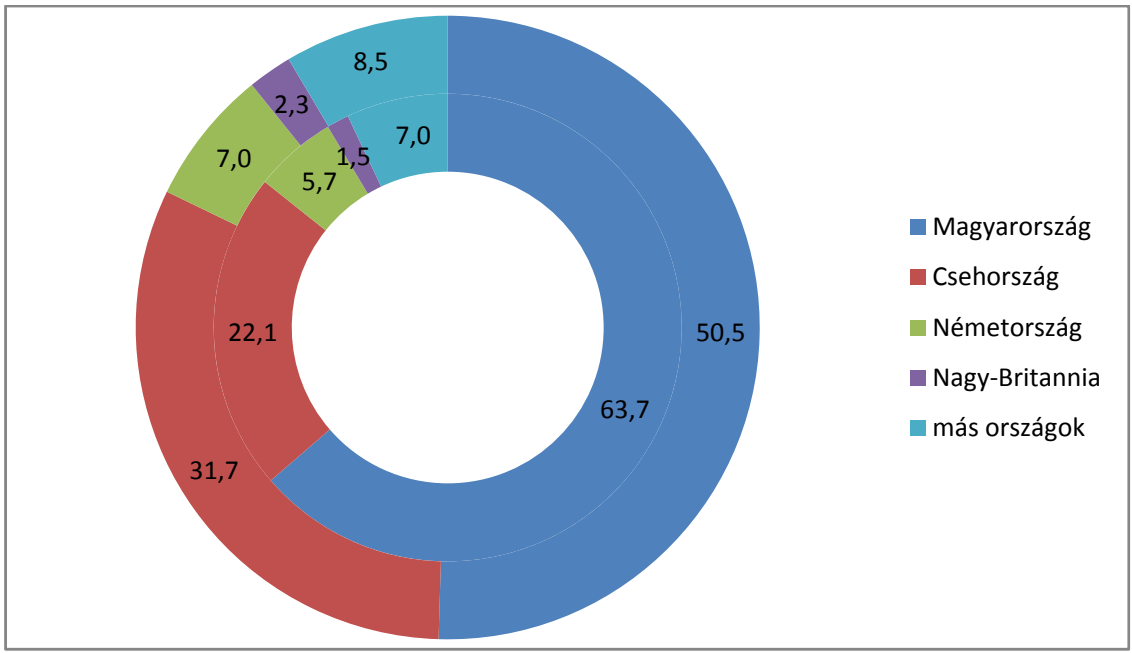

Forrás: Saját szerkesztés

A Summa 2017 kutatás alapján tehát a 2001-es ukrán népszámlálás óta több mint 14 ezer kárpátaljai magyar távozott külföldre, közülük 10 ezren Magyarországra, így az emigráció a magyarok fogyásának a legfőbb oka. Becslésünk szerint 2017 elején a magyar népességnek a 2001-es népszámlálásból továbbvezetett lélekszáma, amely természetesen az egyéni identifikáció változásait, szubjektivitását nem tudja figyelembe venni, 125 ezer fő körül lehetett. ${ }^{18}$ Közülük az ideiglenes migráció keretében 27-28 ezer magyar tartózkodott külföldön legalább 1 hónapot. Utóbbiak közül 18-19 ezren több mint 3 hónapot töltöttek Kárpátalján kívül (főleg Magyarországon). Az évnek legalább a felét 11-12 ezer ember töltötte külföldön.

${ }^{18}$ A felmérés nem terjedt ki a telepeken élő cigány népességre, így a fenti érték a magyar identitású cigány népességet nem tartalmazza. Molnár és szerzőtársai (2016) adatai alapján a magát 2001-ben magyar nemzetiségűnek valló mintegy 4 ezer cigány továbbvezetett száma 2016-ban 5,5 ezer fő. Ezt hozzáadva a felmérés által becsült 125 ezer főhöz megkapjuk a kárpátaljai magyaroknak a 2001-es népszámlálással összevethető létszámát, 131 ezer főt. 


\section{TEMATIKUS TANULMÁNYOK - Kárpátalja társadalma}

\section{Összegzés}

A tanulmányunkban bemutatott négy különböző adatforrás helyenként egybecsengő, de leginkább jelentősen eltérő adatokkal szolgál arról, hogy hány magyar vándorolhatott ki állandó vagy ideiglenes jelleggel Kárpátaljáról 2001 óta. Az adatbázisok összehasonlítása plasztikusan érzékelteti, hogy a különböző módszertannal, különböző aktorok által gyűjtött adatok egyenként sokszor jelentősen eltérő képet festenek ugyanarról az - egyébként meglehetősen komplex és többirányú - folyamatról.

A különböző mozgások technikai követésén túl a folyamatok értelmezése is egyre bonyolultabb. A megnövekedett mobilitás világában szinte lehetetlen egzakt választ adni arra, hogy mekkora egy adott területen élő népesség száma, hiszen a különböző irányú és intenzitású mozgások szétfeszítik a hagyományos statisztikai felvételek (pl. népszámlálás) kereteit. Kárpátalja esetében e kérdések leginkább úgy merülnek fel, hogy hogyan érdemes kezelni a több ezer külföldön munkát vállaló vagy tanuló, adott esetben az év 11 hónapjában távol levő lakost. Aki külföldre költözik, véglegesen költözik-e, avagy beszámítható-e kárpátaljai lakosnak? Hogyan lehet megkülönböztetni az állandónak, illetve ideiglenesnek mondott migránsokat, akik sokszor ugyanolyan típusú mozgásokkal jellemezhetők, és egy évben ugyanannyi időt töltenek Kárpátalján? A fenti kérdésekre adott válaszok mind jelentősen befolyásolhatják azt, hogy hány emberről véljük azt, hogy Kárpátalján élnek.

A vázolt nehézségek ellenére mégis megpróbáljuk számszerūsíteni a kárpátaljai magyarok migrációját. A 2001-2016 közötti időszakot vizsgálva a legalacsonyabb adat - nem meglepő módon - az ukrán statisztikákból körvonalazódik. E szerint e 15 évben mindössze 4-5 ezer magyar kivándorlásával lehet kalkulálni, amiből - a bemutatott felmérések arányait alapul véve - 3-4 ezren telepedhettek át Magyarországra. A magyar tükörstatisztikák azonban teljesen mást mutatnak. A születési hely szerinti statisztikákra alapozva minimálisan 21 ezer (a 2011-es népszámlálás és a 2016-os mikrocenzus adatai alapján), maximálisan 36 ezer (a KSH és az EUROSTAT regiszter alapú statisztikái, valamint Karácsonyi és Kincses (2010) alapján) magyar áttelepedése vezethető le az adatokból. Ha ehhez hozzávesszük a nem Magyarországra költözőket, akik az összes kárpátaljai magyar kivándorló több mint 1/4-ét adják, akkor a kárpátaljai magyar migrációs veszteség 28-48 ezer fő 15 év alatt. Ebből reális lehetőségnek inkább csak az alsó értéket lehet elfogadni. Mindenesetre a hivatalos ukrán és magyar statisztikák szerint 4 és 48 ezer között lehet a ténylegesen kivándoroltak száma, azonban ahogyan azt már jeleztük, különböző okokból előbbi alulbecsüli, utóbbi eltúlozza a jelenséget.

Ezzel szemben a két bemutatott reprezentatív felmérés értéke már jóval közelebb áll egymáshoz. A migrációs vizsgálat alapján az elvándoroltak száma 9 ezer, a demográfiai felmérés szerint 14 ezer. Összességében az utóbbi eredmény tűnik megalapozottabbnak, tekintve a Summa 2017 szélesebb körű mintavételét, valamint a migrációs felmérés vegyesen lakott és szórványtelepüléseken alkalmazott - iskolai 


\section{TEMATIKUS TANULMÁNYOK - Kárpátalja társadalma}

tanulókra alapozott - mintavételi módszerének a véglegesen kitelepültek számának a becslésére való korlátozott alkalmasságát. E két kutatás az ideiglenesen külföldön tartózkodók számában is meglehetősen összecseng (27-28 ezer fő, ebből munkavállalási és tanulási céllal hosszabb időre közel 20 ezer fő).

Ahhoz, hogy a migráció mértékéből következtetni lehessen a magyarok létszámára, ismernünk kell a természetes szaporodás és az asszimiláció mértékét. Előbbi tekintetében a Summa 2017 adataira hagyatkozunk, ami alapján a vizsgált időszakban a természetes fogyás 6,7 ezer fővel csökkentette a magyarok számát. Az asszimiláció tekintetében azt tartjuk irányadónak, hogy a 2001-es népszámlálás szerint az etnikai átörökítés ukrán-magyar viszonylatban közel szimmetrikus volt, a magyarságnak összességében nem volt asszimilációs vesztesége. Így tehát mindegyik modellnél 6,7 ezer fős természetes fogyással és 0 fős asszimilációval kalkuláltunk (1. táblázat).

1. táblázat. A kivándorlás hatása a magyar lakosság számára a négy adatforrás alapján (ezer főben)

\begin{tabular}{|l|c|c|c|c|c|}
\hline \multicolumn{1}{|c|}{ Adatforrás } & $\begin{array}{c}\text { Kivándorlás } \\
\text { (2001-2016) }\end{array}$ & $\begin{array}{c}\text { ebből } \\
\text { Magyar- } \\
\text { országra }\end{array}$ & $\begin{array}{c}\text { Munkavállalási } \\
\text { és tanulási } \\
\text { migráció, 2016 }\end{array}$ & $\begin{array}{c}\text { ebból } \\
\text { Magyar- } \\
\text { országra }\end{array}$ & $\begin{array}{c}\text { Kárpátaljai } \\
\text { magyarok } \\
\text { száma 2017 } \\
\text { elején }\end{array}$ \\
\hline Ukrán statisztikák & 4 & 3 & .. & .. & 141 \\
\hline $\begin{array}{l}\text { Magyar statisztikák } \\
\text { (maximális migrá- } \\
\text { ció) }\end{array}$ & 48 & 36 & .. & .. & 97 \\
\hline $\begin{array}{l}\text { Magyar statisztikák } \\
\text { (minimális migrá- } \\
\text { ció) }\end{array}$ & 28 & 21 & .. & .. & 117 \\
\hline $\begin{array}{l}\text { Migrációs felmérés } \\
2017\end{array}$ & 9 & 6,5 & 20 & 11 & 136 \\
\hline Summa 2017 & 14 & 10 & 19 & 10,5 & $131^{*}$ \\
\hline
\end{tabular}

*A 2001-es népszámlálással és a többi adatforrással összevethető érték. A felmérés a magyar cigányok nélkül 125 ezer fó körülire becsüli a kárpátaljai magyarok számát.

Forrás: Saját szerkesztés

Az 1. táblázatban összefoglalt eredmények szerint a kárpátaljai magyar közösségnek a 2001-es népszámlálásból továbbvezetett lélekszáma 2017-ben legvalószínűbben 130 ezer fő körül lehet. Azonban ha azt vizsgáljuk, hogy hány magyar lakos tartózkodik életvitelszerűen Kárpátalján, ez a szám az ideiglenes migráció miatt 120 ezer alatt van. 


\section{TEMATIKUS TANULMÁNYOK - Kárpátalja társadalma}

A kárpátaljai magyaroknak a következő népszámláláson rögzített számát (ha lesz ilyen) a fentieken túl azonban elsősorban az fogja eldönteni, hogy hány huzamosabban távollevőt fognak családtagjai helyben élőnek bediktálni, hány nemzetiségileg vegyes származású, valamint kettős etnikai öntudatú lakos fogja magát magyar nemzetiségűként meghatározni, illetve hány magyar anyanyelvű roma fogja az adott pillanatban a magyar nemzetiséget választani.

\section{Irodalom}

Çağlar, A. (2013): Circular Migration between Hungary and Ukraine: Historical Legacies, the Economic Crisis, and the Multidirectionality of 'Circular' Migration. In: Triandafyllidou, Anna (ed.): Circular Migration between Europe and its Neighbourhood: Choice or Necessity? Oxford University Press, Oxford: 141-165.

Feischmidt, M. - Zakariás, I. (2010): Migráció és etnicitás. A mobilitás formái és politikái nemzeti és transznacionális térben. In: Feischmidt Margit (szerk.): Etnicitás. Különbségteremtő társadalom. Gondolat-MTA Kisebbségkutató Intézet, Budapest: 152-169.

Gödri, I. (2010): Bevándorlás és etnicitás - összefüggések nyomában. In: Hárs Ágnes - Tóth Judit (szerk.): Változó migráció - változó környezet. MTA Etnikai-nemzeti Kisebbségkutató Intézet, Budapest: 87-124.

Gyurgyík, L. (2004): Asszimilációs folyamatok a szlovákiai magyarság körében. Kalligram, Pozsony

Gyurgyík, L. (2006): Népszámlálás 2001. A szlovákiai magyarság demográfiai-, település-, és társadalomszerkezetének változásai az 1990-es években. Kalligram, Pozsony

Horváth, S. (2003): Magyarság - számok és kétségek. In: Kárpáti Igaz Szó, 19: 4.

Ihnatolja, N. I. (Ігнатоля, Наталія Іллівна) (2012): Трудова міграція Закарпатців: напрямки та тенденції змін. Вісник Львівського університету. Серія соціологічна. 2012 (6): 88-95.

Juhász, J. - Csatári, F. - Makara, E. (2010): Ukrán állampolgárok munkavállalása Magyarországon. Panta Rhei, Budapest

Kántor, Z. (2016): Nemzet, autonómia, kettős állampolgárság. „A megmaradás útjai helyzetkép a külhoni magyarságról” című konferencián Budapesten, 2016. május 30-án elhangzott előadás

Karácsonyi, D. - Kincses, Á. (2010): Az elvándorlás hatása a kárpátaljai magyarság helyzetére. In: Földrajzi Közlemények, 134 (1): 31-44. 
www. metszetek.unideb.hu

\section{TEMATIKUS TANULMÁNYOK - Kárpátalja társadalma}

Kárpátaljai Megyei Statisztikai Főhivatal (Головне управління статистики у Закарпатській області) (2005): Міграція населення. Статистичний бюлетень, Ужгород.

Kárpátaljai Megyei Statisztikai Főhivatal (Головне управління статистики у Закарпатській області) (2006): Міграційний рух населення. Статистичний бюлетень, Ужгород.

Kárpátaljai Megyei Statisztikai Főhivatal (Головне управління статистики у Закарпатській області) (2008, 2011, 2012, 2016): Закарпаття в демографічному вимірі. Статистичний збірник, Ужгород.

Kész, A. (2008): Kárpátaljai diplomás betelepülők az Észak-alföldi Régióban. In: Szarka László - Kötél Emőke (szerk.): Határhelyzetek. Balassi Intézet Márton Áron Szakkollégium, Budapest: 155-167.

Kincses, Á. (2015): A nemzetközi migráció Magyarországon és a Kárpát-medence magyar migrációs hálózatai a 21. század elején. KSH Műhelytanulmányok, Budapest

Kiss, T. (2006): Interethnic Marriages and Assimilation in Demographic Models. In: Balogh Balázs - Ilyés Zoltán. (szerk.): Perspectives of Diaspora Existance. Akadémiai Kiadó, Budapest: 105-137.

Kiss, T. (2012): Demográfiai körkép. A kisebbségi magyar közösségek demográfiai helyzete a Kárpát-medencében. Educatio, 21 (1): 24-48.

Kocsis - K. - Bottlik, Zs. - Tátrai, P. (2006): Etnikai térfolyamatok a Kárpát-medence határainkon túli régióiban (1989-2002). MTA FKI, Budapest

Kovály, K. - Erőss, Á. - Tátrai, P. (2017): „Hát megpróbálunk küzdeni”: átalakuló boldogulási stratégiák Kárpátalján az Euromajdan után. In: Tér és Társadalom, 31 (2): 3-22.

KSH (2016): 2011. évi népszámlálás: Műhelytanulmányok. KSH, Budapest

KSH (2017): Mikrocenzus 2016: Demográfiai adatok. KSH, Budapest

Molnár, D. I. (2005): Migrációs tendenciák Ukrajnában a függetlenség kivívását követően. In: Süli-Zakar István (szerk.): „Tájak- régiók - települések...” - tisztelgés a 75 éves Enyedi György akadémikus előtt. Didakt, Debrecen: 274-278.

Molnár, D. I. (2013): A hatalomváltások hatása Kárpátalja népességszámának alakulására 1869-től napjainkig. PhD-értekezés

Molnár, J. - Molnár, D. I. (2005): Kárpátalja népessége és magyarsága a népszámlálási és népmozgalmi adatok tükrében. Kárpátaljai Magyar Pedagógusszövetség, Ungvár

Molnár, J. (Молнар Йосип) (2016): Національна ідентичність нащадків етнічно змішаних (українсько-угорських) закарпатських родин за даними перепису 


\section{TEMATIKUS TANULMÁNYOK - Kárpátalja társadalma}

населення та анкетного опитування. In: Berghauer Sándor (szerk.): Társadalomföldrajzi kihívások és adekvát válaszlehetőségek a XXI. század Kelet-Közép-Európájában. II. Rákóczi Ferenc Kárpátaljai Magyar Főiskola, Beregszász: 166-174.

Molnár, J. - Csernicskó, I. - Braun, L. (2016): Cigányok Kárpátalján. In: Szilágyi Ferenc - Pénzes János (szerk.): Roma népesség Magyarország északkeleti határtérségében. Partium Kiadó, Nagyvárad: 91-108.

Papp, Z. A. - Ferenc, V. - Márton, J. - Morvai, T. - Szerbhorváth, Gy. - Zsigmond, Cs. (2017): Külhoni magyar fiatalok a Kárpát-medencében. Összefoglaló adatok. In: Papp Z. Attila (szerk.): Változó kisebbség: Kárpát-medencei magyar fiatalok. Mathias Corvinus Collegium - Tihanyi Alapítvány, MTA TK Kisebbségkutató Intézet, Budapest: 193-237.

Soltész, B. - Zimmerer, G. (2014): Migration between the EU, V4 and Eastern Europe: the present situation and possible future. The perspective of Hungary. In: Jaroszewicz, Marta - Lesińska, Magdalena (eds.): Forecasting Migration Between the EU, V4 and Eastern Europe. Impact of Visa abolition. Centre for Eastern Studies, Warsaw: 122-138.

Szanyi, F. E. - Faludi, J. - Illyés, G. (2017): Elvágyódás, elvándorlás - legújabb migrációs folyamatok Kárpátalján. In: Kisebbségi Szemle, 2 (2): 85-108.

Szilágyi, N. S. (2004): Az asszimiláció és hatása a népesedési folyamatokra. In: Kiss Tamás (szerk.): Népesedési folyamatok az ezredfordulón Erdélyben. RMDSZ Ügyvezető Elnöksége, Kolozsvár: 157-234.

Tátrai, P. - Erőss, Á. - Kovály, K. (2017): Kin-state politics stirred by a geopolitical conflict: Hungary's growing activity in post-Euromaidan Transcarpathia, Ukraine. In: Hungarian Geographical Bulletin, 66 (3): 203-218.

Ukrajna Állami Statisztikai Szolgálata (2016): http://www.ukrstat.gov.ua

Varga, E. Á. (2002): Az erdélyi magyarság asszimilációs mérlege a XX. század folyamán. In: Regio, 13 (1): 171-205.

Zan, M. (Зан, Михайло) (2010): Етнічні процеси на Закарпатті в сучасну добу. In: Народна творчість та етнографія, 2010 (1): 31-42. 